\title{
Effects of acupuncture on the gene expression profile of lung tissue from normal rats
}

\author{
LEI-MIAO YIN ${ }^{1}$, YU WANG $^{1}$, YAN WANG ${ }^{1}$, YU-DONG XU $^{1}$, YAN-YAN LIU ${ }^{1}$, \\ WEI-RONG JIN ${ }^{2}$, QING-HUA ZHANG ${ }^{2}$ and YONG-QING YANG ${ }^{1}$ \\ ${ }^{1}$ Shanghai Research Institute of Acupuncture and Meridian, Yue Yang Hospital, Shanghai University of \\ Traditional Chinese Medicine; ${ }^{2}$ National Engineering Center for Biochips at Shanghai, Shanghai, P.R. China
}

Received January 30, 2012; Accepted May 2, 2012

DOI: $10.3892 / \mathrm{mmr} .2012 .909$

\begin{abstract}
Acupuncture has been demonstrated to be an effective treatment for various diseases. However, little attention has been paid to its physiological influences, especially on the changes in protein and mRNA levels following acupuncture treatment under normal conditions. In this study, we investigated the gene expression profile of lung tissue from acupuncture-treated normal rats and attempted to characterize the underlying mechanisms of the changes in expression. Three common acupoints, Dazhui (GV14), fengmen (BL12) and feishu (BL13) were selected for analysis, and 2 serial analyses of gene expression (SAGE) tag libraries of the lung tissues that were derived from the normal and acupuncture-treated rats were established. Bioinformatic analyses were carried out using the functional annotation tools of the Database for Annotation, Visualization and Integrated Discovery (DAVID), the Gene Ontology (GO) Tree Machine and the Kyoto Encyclopedia of Genes and Genomes (KEGG) pathway analysis. In total, 144 tags were differentially expressed $(\mathrm{P}<0.05)$, and the DAVID functional classification of genes demonstrated that the genes were divided into 6 types. Furthermore, GO Tree Machine analysis of the gene categories indicated that 10 enriched GO categories had become enriched after acupuncture, and that 15 KEGG pathways matched the differentially expressed tags of the 2 SAGE libraries. Our results show that the essential effects of acupuncture on normal rats include the regulation of macromolecular biosynthesis, transportation and metabolism. Cellular biosynthesis and cellular lipid metabolism are the common biological processes that occur in response to
\end{abstract}

Correspondence to: Professor Yong-Qing Yang, Shanghai Research Institute of Acupuncture and Meridian, Yue Yang Hospital, Shanghai University of Traditional Chinese Medicine, 650 South Wanping Road, Shanghai 200030, P.R. China

E-mail: yyq@shutcm.edu.cn

Abbreviations: DAVID, Database for Annotation, Visualization and Integrated Discovery; GO, Gene Ontology; KEGG, Kyoto Encyclopedia of Genes and Genomes

Key words: acupuncture, acupoints, serial analysis of gene expression, gene expression profiling, systems biology acupuncture under normal and morbid conditions, which may be the general physiological effects of acupuncture.

\section{Introduction}

Acupuncture is one of the major therapies that has been used in traditional Chinese medicine for at least 2,500 years, and it remains an effective, safe and convenient intervention for patients. Acupuncture practitioners insert thin, solid, metallic needles into specific acupuncture points on the skin known as acupoints, which are special nodes (or outlets) on the meridians. Acupoints are utilized to correct the imbalances of the flow of qi in the body to treat various diseases. The World Health Organization (WHO) listed 43 indications for acupuncture in 1980 (1) and classified the diseases treated by acupuncture into 4 categories, including 107 illnesses, in 2002 (2). The National Institutes of Health (NIH) recommended acupuncture as an adjunctive treatment in comprehensive management programs, such as those for addiction, stroke rehabilitation and asthma $(3,4)$. In recent years, acupuncture has also emerged as an alternative and satisfactory treatment for symptom management in cancer (5), functional gastrointestinal disorders (6) and rheumatic conditions (7).

Acupuncture causes multiple biological alterations in humans (4). In recent years, researchers have attempted to identify changes in active substances after acupuncture and the correlation between the changes in active substances and the effect of acupuncture. It is thought that the therapeutic effect of acupuncture includes 2 parts: the psychological and physiological effects (8). The physiological effect of acupuncture is composed of point-specific, treatment-specific and non-invasive skin contact physiological effects (9). Due to the significant effect on healthy volunteers $(10,11)$, the condition-specific physiological effect is thought to be one of the most important physiological effects of acupuncture. Although a large number of studies have been carried out to examine the effects of acupuncture under different morbid conditions, the regulatory mechanism of acupuncture remains unclear, and the evidence that has been acquired is not compelling. We will only be able to distinguish the effects of acupuncture on specific active substances under morbid conditions once we are able to accurately analyze the general effects of acupuncture under normal conditions, and clarify the regulatory mechanisms involved. 
Previous studies have shown that acupuncture in healthy volunteers has given rise to biological responses that regulate important physiological processes. Using functional magnetic resonance imaging (fMRI) of the brain, a previous randomized, controlled trial showed that acupuncture improves motor and sensory functions in healthy volunteers (12). There was a statistically significant increase in the number of $\mathrm{CD}^{+}$and $\mathrm{CD}^{+}$cells, and in interleukin (IL)-4, IL-1 $\beta$ and interferon- $\gamma$ (IFN- $\gamma$ ) levels in the cells after stimulation of meridian points by acupuncture (13). Acupuncture also modifies the mediation of the autonomic innervations of the heart. Acupuncture at the PC6 (wrists) and ST36 (lower legs) points has been shown to help athletes significantly decrease their maximum heart rate, oxygen consumption and blood lactic acid production $30 \mathrm{~min}$ after exercise (14). It has been reported that both specific and non-specific factors may play a role in acupuncture therapy for pain; however, only real acupuncture (non-placebo) has shown specific physiological effects (15). Another study demonstrated that the physiological effects of acupuncture may be influenced by anxiety (16). Additionally, acupuncture treatment regulates autonomic nervous system functions, such as blood pressure regulation, sphincter of Oddi relaxation, immune modulation (17) and electrodermal activity (18). However, gene expression profile studies on the physiological effects of acupuncture under normal conditions are still lacking.

High-throughput technologies, such as microarray and serial analyses of gene expression (SAGE), may help to reveal the background gene expression in response to acupuncture and highlight the regulatory mechanism of acupuncture under morbid conditions. SAGE, a powerful expression profiling method that is very useful in dissecting this complex system, has been applied to qualitatively and quantitatively evaluate the transcription of genes by length without the prerequisite of a hybridization probe for each transcript (19).

In this study, two SAGE tag libraries from the lung tissues of normal and acupuncture-treated rats were constructed. The aim of this study was to determine the influence of acupuncture on the gene expression profiles of lung tissue from normal rats. The results from this analysis may elucidate the regulatory mechanism of acupuncture under normal conditions and help to specify its effects under morbid conditions in the future.

\section{Materials and methods}

Animal and acupuncture treatment. Pathogen-free, male, Sprague-Dawley (SD) rats (4 weeks of age, 110-130 g; SLAC Laboratory Animal Co. Ltd., Shanghai, China) were raised in a pathogen-free, rodent facility and were provided with food and water ad libitum. The rats were randomly divided into 2 groups (each group contained 8 rats): normal rats (control) and normal rats treated with acupuncture. The rats were kept in animal facilities that had been approved by the Shanghai Committee for Accreditation of Laboratory Animals, and the animal experiments conformed to the regulations of the State Science and Technology Commission.

Three common acupoints for treating lung-related diseases were selected and manipulated at the same time in the acupuncture group, namely dazhui (GV14, located between the C7 and T1 vertebrae), bilateral fengmen (BL12, foveola, located laterally between the T2 and T3 vertebrae) and bilat- eral feishu (BL13, foveola, located laterally between the T3 and T4 vertebrae). Manual acupuncture was performed once every other day for 2 weeks by a well-trained acupuncturist (7 times in total). The protocol of acupuncture treatment has been described previously (20). Briefly, disposable, stainless needles $(0.30 \times 13 \mathrm{~mm})$ were inserted $\sim 5 \mathrm{~mm}$ deep into the skin, and the needles were twisted evenly, $\sim 360^{\circ}$, at the rate of $60 \mathrm{times} / \mathrm{min}$ for $20 \mathrm{sec}$. The needles were manipulated every $5 \mathrm{~min}$, and were then withdrawn after $20 \mathrm{~min}$. Each rat was placed on a suspended shelf $(50 \times 45 \mathrm{~mm}, \sim 50 \mathrm{~cm}$ above the ground) in order to allow the animal to stand still without anesthesia. Rats in the control group were handled in the same manner as the animals in the acupuncture group, with the exception of acupuncture treatments. At the end of 2 weeks, all animals were sacrificed. Total RNA was extracted from the lungs of the rats and frozen immediately in liquid nitrogen.

Construction, annotation and confirmation of the SAGE libraries. The construction and annotation of the SAGE libraries have been described previously (21). The confirmation of the 2 SAGE libraries was performed by quantitative real-time PCR (qRT-PCR) on an Applied Biosystems 7300 Real-Time PCR System using the Toyobo Real-time PCR Master Mix (Toyobo, Osaka, Japan). Primer sequences are listed in Table I. The expression ratio was calculated according to the $2^{-\Delta \Delta \mathrm{Ct}}$ method (22). Transcripts with a 2-fold increase in expression were considered upregulated, and those with a 0.5 -fold decrease in expression were considered downregulated.

Bioinformatic analysis of SAGE tags. Genes that were differentially expressed $(\mathrm{P}<0.05)$ between the 2 SAGE libraries were functionally annotated and classified using the Database for Annotation, Visualization and Integrated Discovery (DAVID) Functional Annotation Tool (http://david.abcc.ncifcrf.gov/), a web-based tool that provides integrated solutions for the annotation and analyses of genome-scale datasets that are derived from high-throughput technologies, such as microarray or SAGE (23).

To understand the key regulatory processes in acupuncture treatment, the Gene Ontology (GO) Tree Machine (http:// www.genereg.ornl.gov/gotm/) was applied for bioinformatic analyses of the acupuncture-regulated expression data. The GO Tree Machine generates a tree-like structure that is used to navigate the GO categories for the input gene sets (24). Statistical analyses of the enrichments were performed to identify the most significant GO categories of the input gene sets and to suggest their potential biological importance in the categories.

Statistical analyses. Statistical analyses used to determine the significance of each of the 2 SAGE libraries were performed using Monte Carlo analysis. The enrichments of the GO Tree Machine were determined to be statistically significant by the hypergeometric test (24).

\section{Results}

General analysis of SAGE libraries. The 2 SAGE libraries of the rat lungs were deposited into the SAGEmap database at the National Center for Biotechnology Information (NCBI; http:// 
Table I. Primer sequences of the real-time PCR.

\begin{tabular}{ll}
\hline Genes & \multicolumn{1}{c}{ Sequences $\left(5^{\prime}-3^{\prime}\right)$} \\
\hline Sftpa1 & $\begin{array}{l}\text { Forward AGCCAGTTTCGCATTCCCT } \\
\text { Reverse ATGTGAAGGCCCATGAGCA }\end{array}$ \\
Col6a2 & $\begin{array}{l}\text { Forward ATGGAAGCCAGAACCAGCAAC } \\
\text { Reverse CCACGTGCGAGAAAGAATTGA }\end{array}$ \\
Col4a1 & Forward GCAATGCTGAATCGTCCCA \\
& Reverse TGGAGATGCCAGATGGTTAGG \\
GAPDH & Forward TCCTGCACCACCAACTGCTTAG \\
& Reverse AGTGGCAGTGATGGCATGGACT
\end{tabular}

Sftpa1, surfactant, pulmonary-associated protein A1; Col6a2, procollagen, the $\alpha 2$ chain of collagen VI; Col4a1, procollagen, the $\alpha 1$ chain of collagen IV.

Table II. Summary of serial analysis of gene expression (SAGE) analysis of the 2 libraries.

\begin{tabular}{lcc}
\hline SAGE tag & Control & Acupuncture \\
\hline Total tags & 28,284 & 29,284 \\
Unique tags & 12,857 & 12,412 \\
Genes matched & $54.1 \%$ & $50.5 \%$ \\
ESTs matched & $38.5 \%$ & $17.0 \%$ \\
Not matched & $7.4 \%$ & $32.5 \%$ \\
\hline
\end{tabular}

EST, expressed sequence tag.

www.ncbi.nlm.nih.gov/geo), and the accession numbers given to these libraries are GSM45195 and GSM279945. The genes that were matched to the expressed sequence tags (ESTs) of the 2 libraries are listed in Table II. By comparing the SAGE data of the control and acupuncture libraries, 144 differentially expressed tags $(\mathrm{P}<0.05$, Table III) were identified. Among these tags, 78 were upregulated and 66 were downregulated.

Confirmation of SAGE results by $q R T-P C R$. To confirm the expression profiles of the 2 SAGE libraries, 3 genes of interest that were differentially expressed before and after acupuncture were chosen, and their expression levels were evaluated by qRT-PCR. The first gene encodes surfactant, pulmonaryassociated protein A1 (Sftpa1), which binds to surfactant phospholipids and aids in decreasing the surface tension at the air-liquid interface in the alveoli of the mammalian lung. This process occurs in the presence of calcium ions and is essential for normal respiration. The second gene encodes procollagen, the $\alpha 2$ chain of collagen VI (Col6a2), which is a major constituent of microfibrils that are found in different organs and tissues and may play an important role in cell migration and differentiation. The third gene encodes procollagen, the $\alpha 1$ chain of collagen IV (Col4a1), which is the major structural component of basement membranes. The expression profiles of the representative genes by qRT-PCR analysis corresponded to the SAGE profiles (Fig. 1), thus validating our

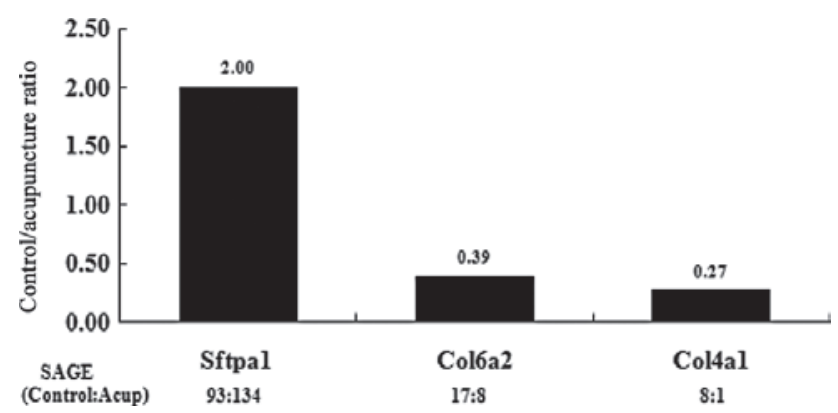

Figure 1. Quantitative real-time PCR (qRT-PCR) confirmation of differentially regulated genes of interest, as predicted by serial analysis of gene expression (SAGE). The expression levels of Sftpa1 in normal rats treated with acupuncture (Acup) were upregulated by 2 -fold, when compared to the control. The expression levels of Col6a 2 and Col4a1 in the Acup group were downregulated by $>0.5$-fold, when compared to the control. Sftpa1, surfactant, pulmonary-associated protein A1; Col6a2, procollagen, type VI, $\alpha 2$; Col4a1, procollagen, type IV, $\alpha 1$.

data and indicating that our data sets could be used for further bioinformatic analyses.

DAVID gene functional classification. For the functional annotation of the differentially expressed genes, 110 known genes and 12 ESTs with a UniGene ID were assigned by applying the DAVID functional annotation tool to the data sets. Of the 122 UniGenes, 105 were functionally classified into 18 groups using the default settings (medium classification stringency) and all GO terms for biological processes. Among these 18 groups, 6 had enrichment scores (ES) that were $\geq 1$. These groups included 'cellular biosynthetic processes' (51 genes, $\mathrm{ES}=2.04)$, 'cellular metabolic processes' (78 genes, ES=1.78), 'cell proliferation' (37 genes, $\mathrm{ES}=1.58$ ), 'cellular lipid metabolic processes' (10 genes, $\mathrm{ES}=1.34)$, 'defense response' (10 genes, $\mathrm{ES}=1.3$ ) and 'transport' (25 genes, $\mathrm{ES}=1.11)$. The gene lists of each group are shown in Table IV.

Analysis of gene categories by GO Tree Machine. In total, 10 GO categories were enriched after acupuncture, and these categories included 'biosynthesis' (16 genes), 'cellular biosynthesis' (14 genes), 'macromolecule biosynthesis' (11 genes), 'protein biosynthesis' (11 genes), 'protein kinase C activation' (2 genes), 'cytolysis' (2 genes), 'vesicle targeting' (2 genes), 'regulation of liquid surface tension' (2 genes), 'mRNA transport' (2 genes) and 'mRNA export from the nucleus' (2 genes). The gene lists of each category are shown in the Table V.

Finding KEGG pathways. To understand the functional roles of the differentially expressed genes, KEGG pathway analysis was assigned by applying the DAVID annotation tool. Fifteen KEGG pathways matched the differentially expressed tags of the 2 libraries (Table VI). Two of these pathways, 'soluble (N-ethylmaleimide-sensitive fusion) NSF attachment protein receptor (SNARE) interactions in vesicular transport' and 'tight junction' pathways, were matched to 3 UniGenes. SNAREs are small, abundant, plasma membrane-bound proteins; the cyclic assembly and disassembly of the SNARE complex is required for regulated secretory vesicle fusion with the plasma membrane. Tight junctions are the closely associ- 


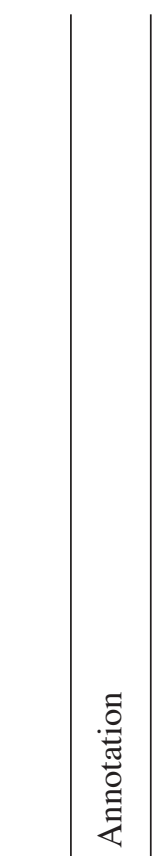

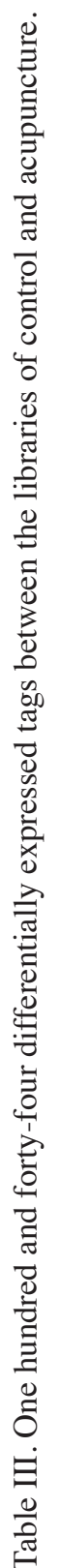
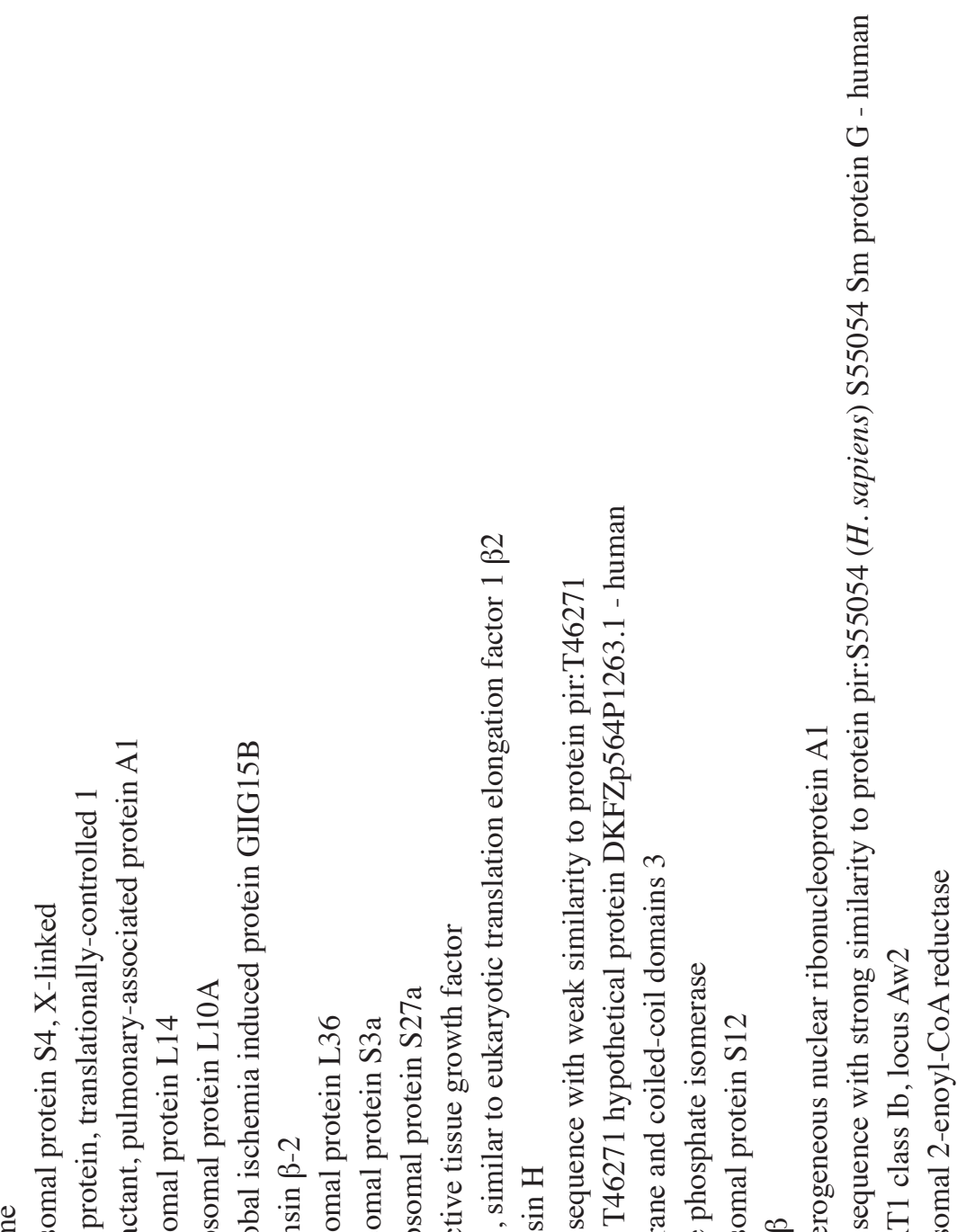

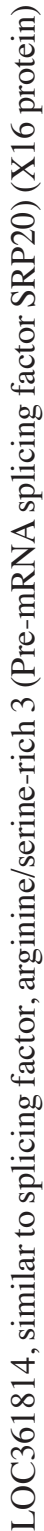

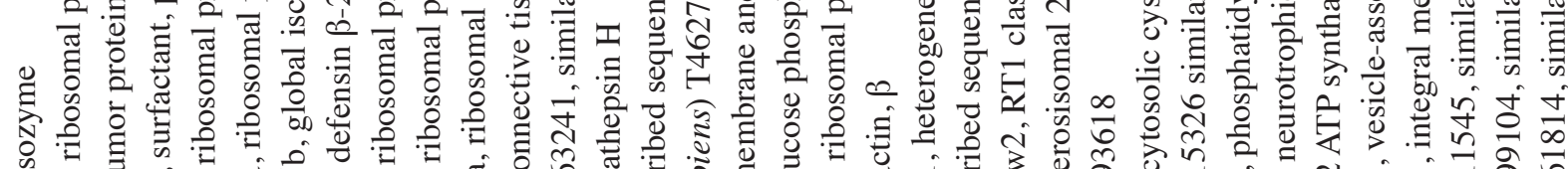

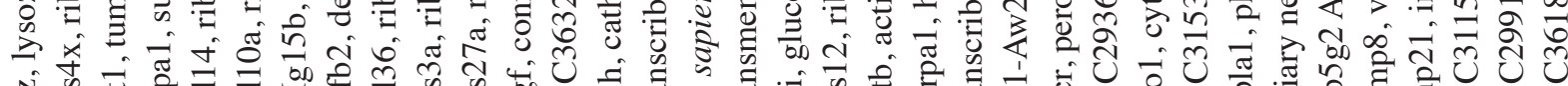

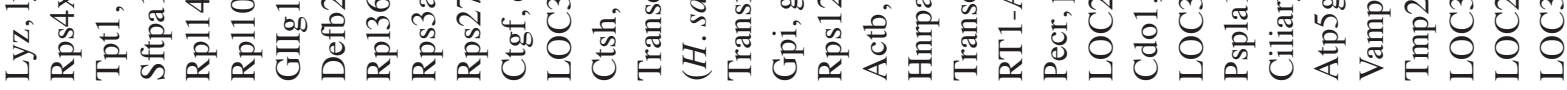

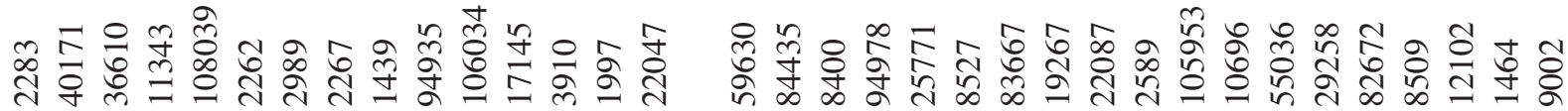

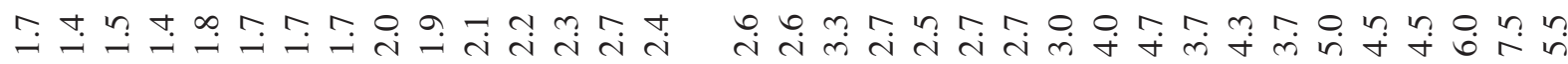

बे

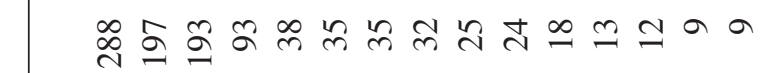

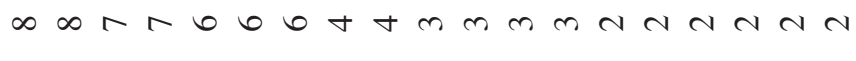

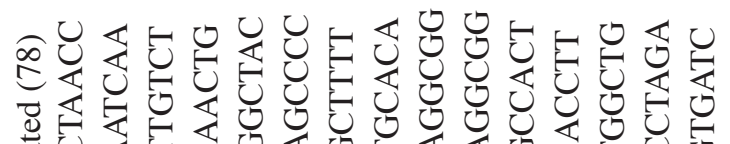

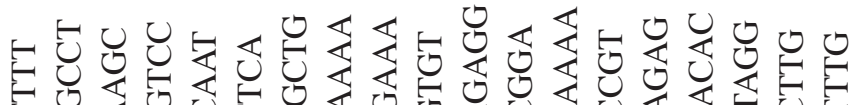

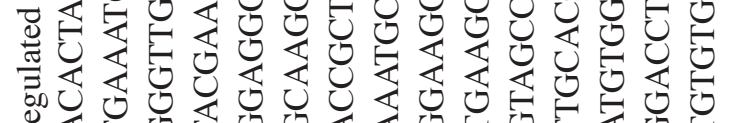

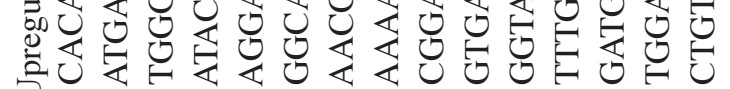




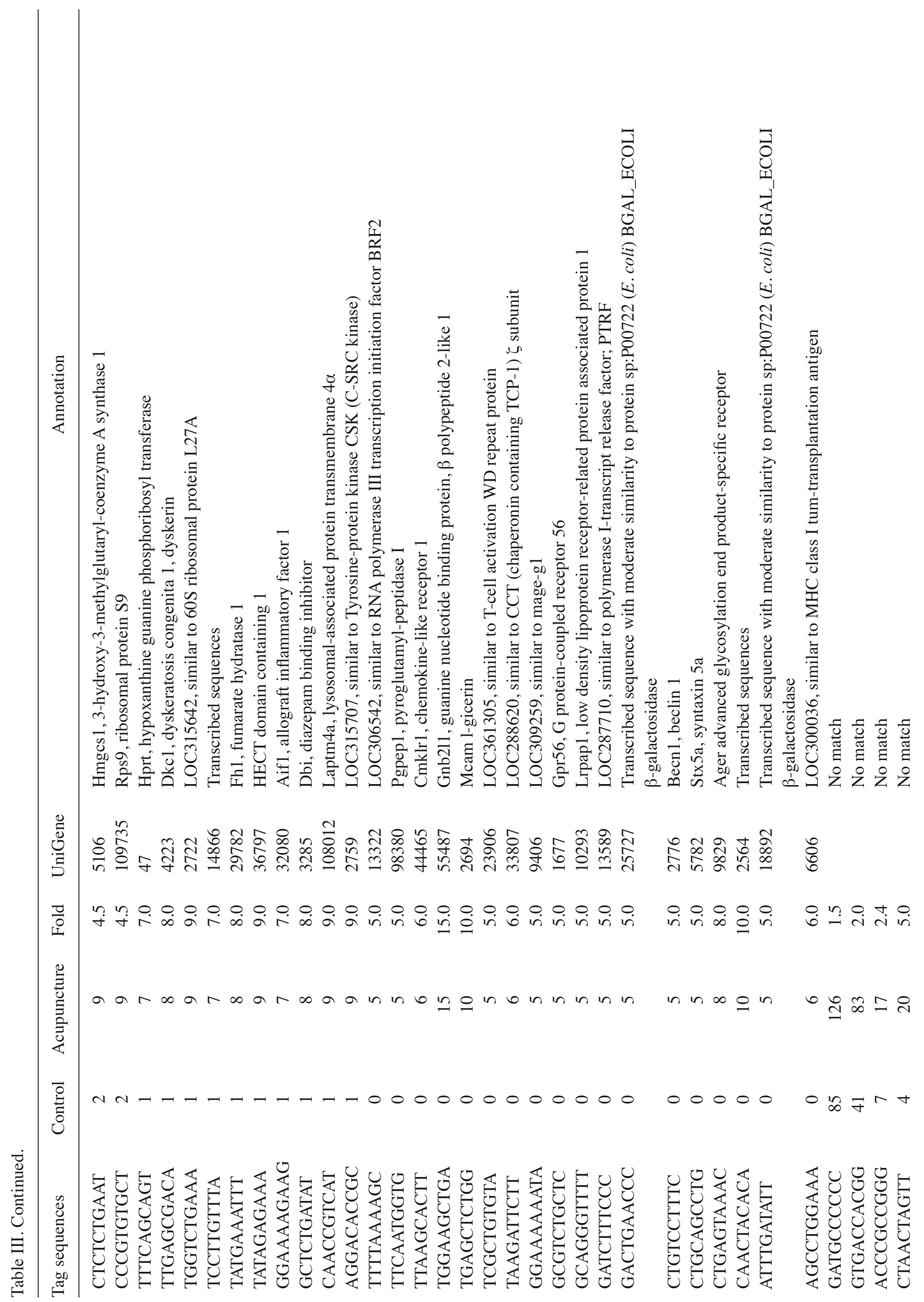




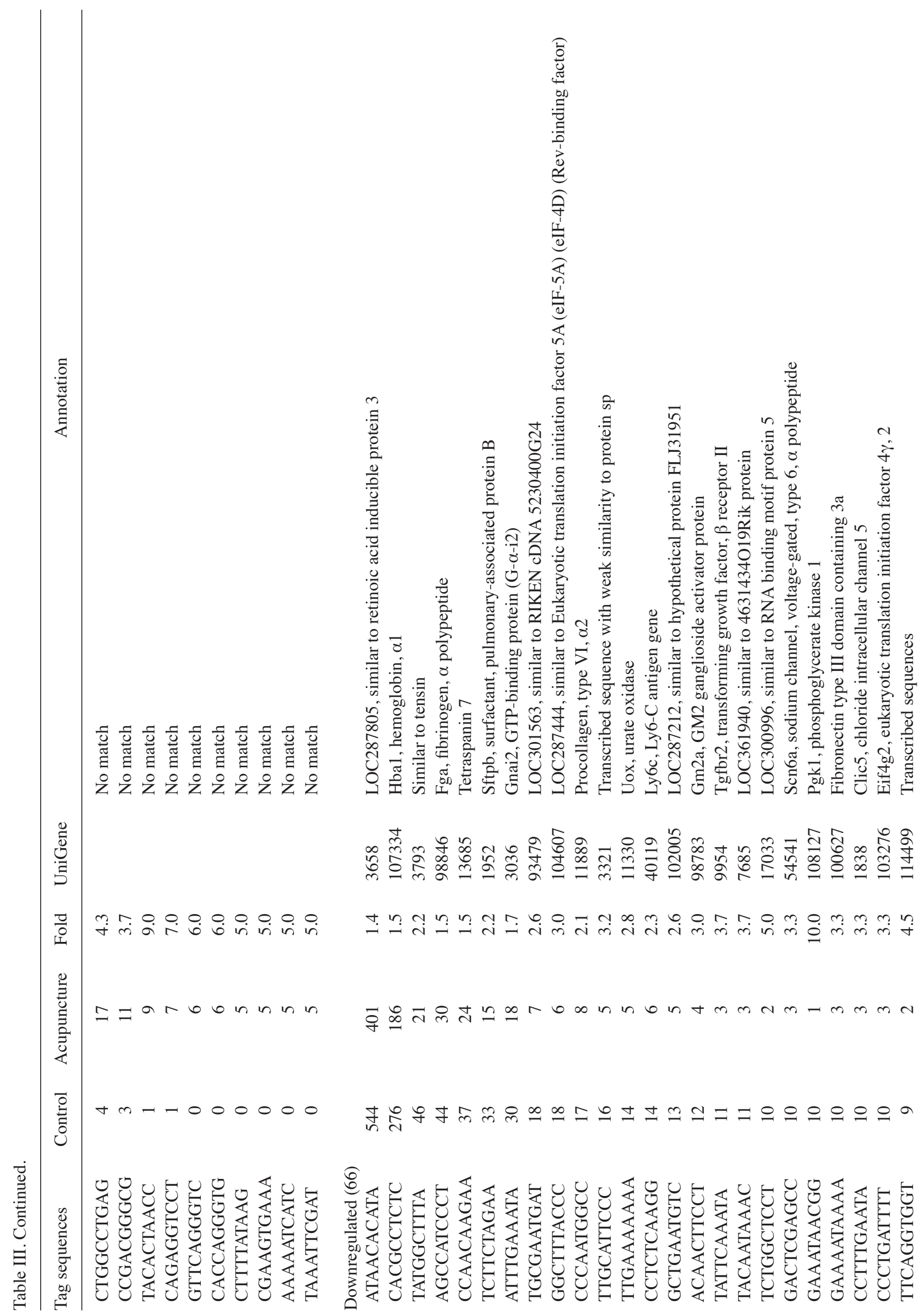




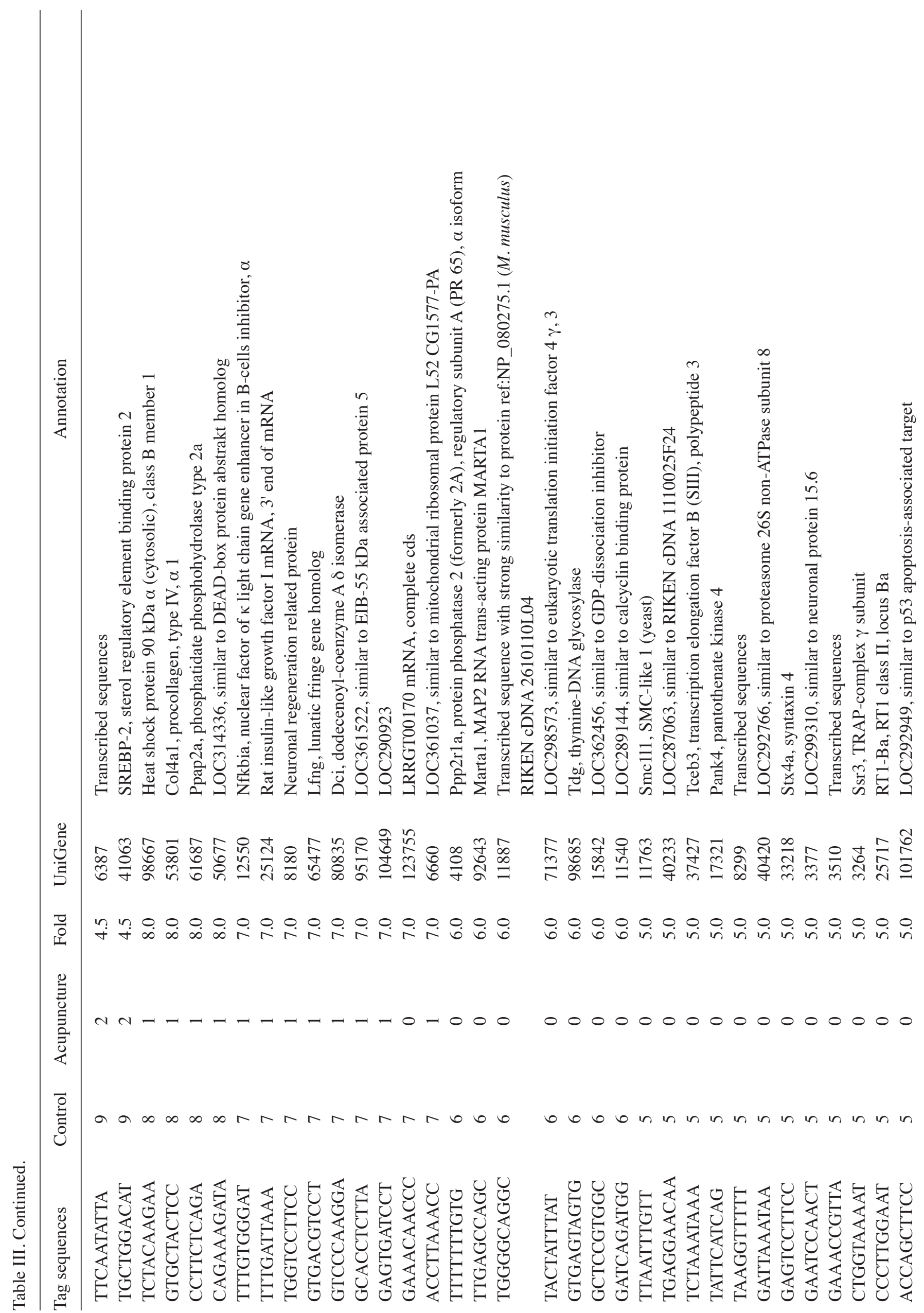




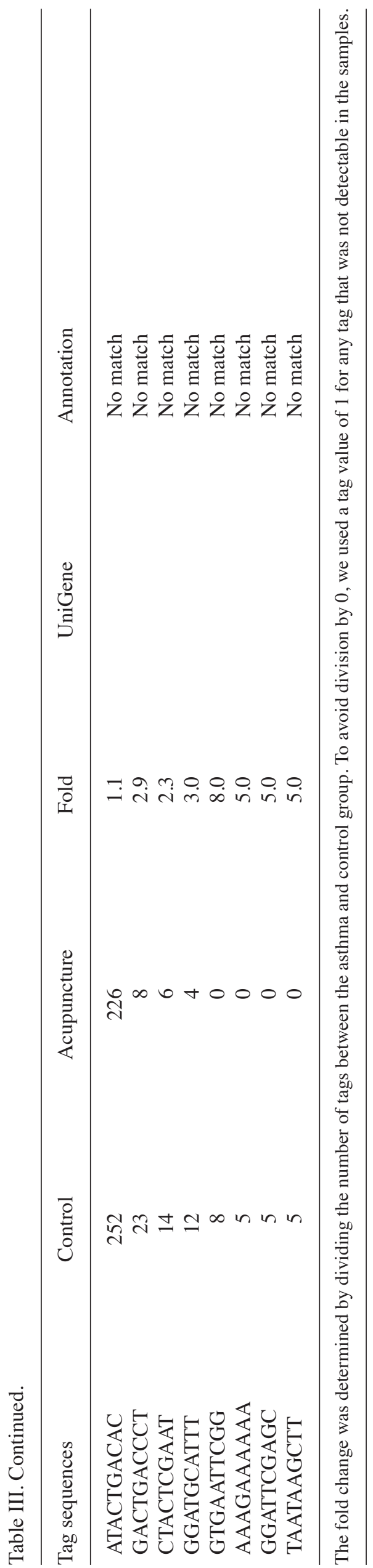

ated areas between 2 cells whose membranes join to form a virtually impermeable barrier to fluid.

\section{Discussion}

A number of experiments and theories have been used to explain the possible mechanisms of acupuncture, which are believed to have a strong biological basis (4). In contrast to target-specific and one-way adjustment chemical reagents, acupuncture upregulates various organ systems that are hypofunctional, or downregulates hyperfunctional systems. Acupuncture is considered as a mechanical activation and signaling process (25). The observation and identification of the global alterations in gene expression in response to acupuncture that are involved in specific physiological processes will help to integrate the knowledge of the underlying signaling and metabolic pathways, biosynthetic processes and the functional interactions of cells, tissues and organs (26). The present study provides abundant experimental data and reveals the background gene expression profile in rats before and after acupuncture treatment. This information highlights the active gene alterations in a particular disease.

DAVID functional classification suggested that the genes involved in metabolism were regulated after acupuncture intervention. These genes included those with roles in 'cellular biosynthetic processes', 'cellular lipid metabolic processes' and 'transport'. The corresponding regulated genes included the following: glucose phosphate isomerase, $\beta$-actin and lysozyme. Glucose phosphate isomerase is an enzyme that catalyzes the conversion of glucose-6-phosphate into fructose6 -phosphate in the second step of glycolysis. $\beta$-actin is one of 6 different actin isoforms that have been identified in humans and is one of most important non-muscle, cytoskeletal actins that have highly conserved roles in cell motility, structure and integrity. Lysozyme is an enzyme that damages the cell walls of bacteria, which are abundant in a number of secretions, such as tears, saliva, human milk and mucus. Finding these genes in our study indicates that dynamic changes occur involving various biological processes and that protein, lipid and sugar synthesis are adjusted separately after acupuncture. In this way, acupuncture completes the regulation of nerve and body fluids.

The GO Tree Machine analysis of the gene categories suggested that acupuncture influences the processes of RNA transcription and protein translation. In the SAGE libraries, genes known as 'KH-type splicing regulatory protein (KHSRP)' and 'heterogeneous nuclear ribonucleoprotein A1' belong to the gene categories of 'mRNA transport' and 'mRNA export from the nucleus'. This finding indicates that acupuncture may influence the expression of these 2 genes to regulate the movement of mRNA from the nucleus to the cytoplasm. By doing so, acupuncture controls mRNA expression and protein translation at its source. The category termed 'regulation of liquid surface tension' included 2 genes, 'Sftpal' and 'surfactant associated protein C'. After inserting the needle into the point of feishu (BL13), the expression of these proteins was increased. This indicated that the change in expression may be a specific effect of the selected acupuncture point.

Fifteen pathways were identified as regulated by acupuncture treatment using KEGG pathway analysis. One of these 
Table IV.List of the Database for Annotation, Visualization and Integrated Discovery (DAVID) gene functional classification groups.

\begin{tabular}{|c|c|c|c|}
\hline Classification & $\begin{array}{l}\text { Enrichment } \\
\text { score }\end{array}$ & UniGene & Annotation \\
\hline \multirow{51}{*}{$\begin{array}{l}\text { Cellular biosynthetic } \\
\text { process }\end{array}$} & \multirow[t]{51}{*}{2.04} & Rn.9954 & Transforming growth factor, $\beta$ receptor ii \\
\hline & & Rn.1997 & Cathepsin h \\
\hline & & Rn.2589 & Cysteine dioxygenase 1 , cytosolic \\
\hline & & Rn.98380 & Pyroglutamyl-peptidase i \\
\hline & & Rn.29258 & $\begin{array}{l}\text { Similar to atp synthase, } h+\text { transporting, mitochondrial f0 complex, } \\
\text { subunit c (subunit 9), isoform } 2\end{array}$ \\
\hline & & Rn.108039 & Ribosomal protein 114 \\
\hline & & Rn.17145 & Connective tissue growth factor \\
\hline & & Rn.84435 & Glucose phosphate isomerase \\
\hline & & Rn.36797 & Similar to hect domain containing 1 \\
\hline & & Rn.82672 & Vesicle-associated membrane protein 8 \\
\hline & & Rn.13589 & Polymerase $\mathrm{i}$ and transcript release factor \\
\hline & & Rn.37427 & Transcription elongation factor b (siii), polypeptide 3 \\
\hline & & Rn.98846 & Fibrinogen, $\alpha$ polypeptide \\
\hline & & Rn.17321 & Pantothenate kinase 4 \\
\hline & & $\operatorname{Rn} .3510$ & Similar to bb128963 protein \\
\hline & & $\operatorname{Rn} .2722$ & Ribosomal protein $127 \mathrm{a}$ \\
\hline & & Rn.103276 & Eukaryotic translation initiation factor $4 \gamma, 2$ \\
\hline & & Rn.17033 & Rna binding motif protein 5 \\
\hline & & Rn.61687 & Phosphatidic acid phosphatase $2 \mathrm{a}$ \\
\hline & & Rn.11763 & Structural maintenance of chromosomes 1 like 1 (S. cerevisiae) \\
\hline & & $\operatorname{Rn} .47$ & Hypoxanthine guanine phosphoribosyl transferase \\
\hline & & Rn.13322 & Brf2, subunit of rna polymerase iii transcription initiation factor, brf1-like \\
\hline & & Rn.19267 & Peroxisomal trans-2-enoyl-CoA reductase \\
\hline & & Rn.94935 & Ribosomal protein s3a \\
\hline & & Rn.2759 & C-src tyrosine kinase \\
\hline & & Rn.92643 & KH-type splicing regulatory protein \\
\hline & & $\operatorname{Rn} .3285$ & Diazepam binding inhibitor \\
\hline & & $\operatorname{Rn} .25771$ & Heterogeneous nuclear ribonucleoprotein a1 \\
\hline & & Rn.98667 & Heat shock $90 \mathrm{kda}$ protein $1, \beta$ \\
\hline & & Rn.9406 & Necdin-like 2 \\
\hline & & Rn.8400 & Ribosomal protein s12 \\
\hline & & Rn.33807 & Chaperonin subunit $6 \mathrm{a}(\zeta)$ \\
\hline & & Rn.106034 & Ribosomal protein s27a \\
\hline & & Rn.98783 & $\mathrm{Gm} 2$ ganglioside activator protein \\
\hline & & Rn.29782 & Fumarate hydratase 1 \\
\hline & & $\mathrm{Rn} .4223$ & Dyskeratosis congenita 1 , dyskerin \\
\hline & & Rn.71377 & Eukaryotic translation initiation factor $4 \gamma, 3$ \\
\hline & & Rn.5106 & 3-Hydroxy-3-methylglutaryl-coenzyme a synthase 1 \\
\hline & & Rn.3910 & Eukaryotic translation elongation factor $1, \beta 2$ \\
\hline & & Rn.2989 & Homeobox only domain \\
\hline & & Rn.11540 & Similar to calcyclin binding protein \\
\hline & & Rn.94978 & Actin, $\beta$ \\
\hline & & Rn.41063 & Sterol regulatory element binding factor 2 \\
\hline & & Rn.104649 & Aspartylglucosaminidase \\
\hline & & Rn.6606 & Tissue specific transplantation antigen $\mathrm{p} 35 \mathrm{~b}$ \\
\hline & & Rn.1439 & Ribosomal protein 136 \\
\hline & & Rn.98685 & Thymine-dna glycosylase \\
\hline & & Rn.107334 & Hemoglobin $\alpha$, adult chain 1 \\
\hline & & Rn.109735 & Ribosomal protein s9 \\
\hline & & Rn.2262 & Ribosomal protein 110a \\
\hline & & Rn.108127 & Phosphoglycerate kinase 1 \\
\hline
\end{tabular}


Table IV. Continued.

\begin{tabular}{|c|c|c|c|}
\hline Classification & $\begin{array}{l}\text { Enrichment } \\
\text { score }\end{array}$ & UniGene & Annotation \\
\hline \multirow{51}{*}{$\begin{array}{l}\text { Cellular metabolic } \\
\text { process }\end{array}$} & \multirow[t]{51}{*}{1.78} & Rn.9954 & Transforming growth factor, $\beta$ receptor ii \\
\hline & & Rn.1997 & Cathepsin $\mathrm{h}$ \\
\hline & & Rn.2589 & Cysteine dioxygenase 1 , cytosolic \\
\hline & & Rn.29258 & $\begin{array}{l}\text { Similar to atp synthase, } h+\text { transporting, mitochondrial f0 complex, } \\
\text { subunit c (subunit 9), isoform } 2\end{array}$ \\
\hline & & Rn.98380 & Pyroglutamyl-peptidase i \\
\hline & & Rn.55036 & Ciliary neurotrophic factor receptor \\
\hline & & Rn.108039 & Ribosomal protein 114 \\
\hline & & Rn.17145 & Connective tissue growth factor \\
\hline & & Rn.3793 & Similar to tensin \\
\hline & & Rn.84435 & Glucose phosphate isomerase \\
\hline & & Rn.8509 & Transmembrane trafficking protein 21 \\
\hline & & Rn.36797 & Similar to hect domain containing 1 \\
\hline & & Rn.82672 & Vesicle-associated membrane protein 8 \\
\hline & & Rn.13589 & Polymerase i and transcript release factor \\
\hline & & Rn.37427 & Transcription elongation factor b (siii), polypeptide 3 \\
\hline & & Rn.98846 & Fibrinogen, $\alpha$ polypeptide \\
\hline & & Rn.108012 & Lysosomal-associated protein transmembrane $4 \mathrm{a}$ \\
\hline & & Rn.17321 & Pantothenate kinase 4 \\
\hline & & Rn.3510 & Similar to bb128963 protein \\
\hline & & Rn.103276 & Eukaryotic translation initiation factor $4 \gamma, 2$ \\
\hline & & Rn.2722 & Ribosomal protein $127 \mathrm{a}$ \\
\hline & & Rn.17033 & Rna binding motif protein 5 \\
\hline & & Rn.3264 & Signal sequence receptor, $\gamma$ \\
\hline & & Rn.11763 & Structural maintenance of chromosomes 1 like 1 (S. cerevisiae) \\
\hline & & Rn.61687 & Phosphatidic acid phosphatase $2 \mathrm{a}$ \\
\hline & & Rn.47 & Hypoxanthine guanine phosphoribosyl transferase \\
\hline & & Rn.13322 & Brf2, subunit of rna polymerase iii transcription initiation factor, brf1-like \\
\hline & & Rn.19267 & Peroxisomal trans-2-enoyl-CoA reductase \\
\hline & & Rn.2759 & C-src tyrosine kinase \\
\hline & & Rn.94935 & Ribosomal protein s3a \\
\hline & & Rn.105953 & Tensin like $\mathrm{c} 1$ domain containing phosphatase \\
\hline & & Rn.101762 & Perp, tp53 apoptosis effector \\
\hline & & Rn.92643 & KH-type splicing regulatory protein \\
\hline & & Rn.3285 & Diazepam binding inhibitor \\
\hline & & Rn.3036 & Guanine nucleotide binding protein, $\alpha$ inhibiting 2 \\
\hline & & Rn.32080 & Allograft inflammatory factor 1 \\
\hline & & Rn.44465 & Chemokine-like receptor 1 \\
\hline & & Rn.1677 & G protein-coupled receptor 56 \\
\hline & & Rn.25771 & Heterogeneous nuclear ribonucleoprotein a1 \\
\hline & & Rn.98667 & Heat shock 90 kda protein $1, \beta$ \\
\hline & & Rn.9406 & Necdin-like 2 \\
\hline & & Rn.8400 & Ribosomal protein s12 \\
\hline & & Rn.36610 & Tumor protein, translationally-controlled 1 \\
\hline & & Rn.22087 & Interferon induced transmembrane protein 1 \\
\hline & & Rn.9829 & Advanced glycosylation end product-specific receptor \\
\hline & & Rn.2776 & Beclin 1 (coiled-coil, myosin-like bcl2-interacting protein) \\
\hline & & Rn.33807 & Chaperonin subunit $6 \mathrm{a}(\zeta)$ \\
\hline & & Rn.106034 & Ribosomal protein s27a \\
\hline & & Rn.98783 & Gm2 ganglioside activator protein \\
\hline & & Rn.29782 & Fumarate hydratase 1 \\
\hline & & Rn.1952 & Surfactant associated protein $b$ \\
\hline
\end{tabular}


Table IV. Continued.

\begin{tabular}{|c|c|c|c|}
\hline Classification & $\begin{array}{l}\text { Enrichment } \\
\text { score }\end{array}$ & UniGene & Annotation \\
\hline & & $\begin{array}{l}\text { Rn.4223 } \\
\text { Rn.71377 } \\
\text { Rn.80835 } \\
\text { Rn.5106 } \\
\text { Rn.3910 } \\
\text { Rn.2989 } \\
\text { Rn.11540 } \\
\text { Rn.94978 } \\
\text { Rn.55487 } \\
\text { Rn.2283 } \\
\text { Rn.41063 } \\
\text { Rn.104649 } \\
\text { Rn.12550 } \\
\text { Rn.6606 } \\
\text { Rn.1439 } \\
\text { Rn.11330 } \\
\text { Rn.98685 } \\
\text { Rn.107334 } \\
\text { Rn.10696 } \\
\text { Rn.2694 } \\
\text { Rn.109735 } \\
\text { Rn.15842 } \\
\text { Rn.2262 } \\
\text { Rn.108127 } \\
\text { Rn.5782 } \\
\text { Rn.3658 } \\
\text { Rn.33218 }\end{array}$ & $\begin{array}{l}\text { Dyskeratosis congenita } 1 \text {, dyskerin } \\
\text { Eukaryotic translation initiation factor } 4 \gamma, 3 \\
\text { Dodecenoyl-coenzyme a } \delta \text { isomerase } \\
\text { 3-Hydroxy-3-methylglutaryl-coenzyme a synthase } 1 \\
\text { Eukaryotic translation elongation factor } 1 \beta 2 \\
\text { Homeobox only domain } \\
\text { Similar to calcyclin binding protein } \\
\text { Actin, } \beta \\
\text { Guanine nucleotide binding protein (g protein) } \\
\text { Lysozyme } \\
\text { Sterol regulatory element binding factor } 2 \\
\text { Aspartylglucosaminidase } \\
\text { Nuclear factor of } \kappa \text { light chain gene enhancer in b-cells inhibitor, } \alpha \\
\text { Tissue specific transplantation antigen p35b } \\
\text { Ribosomal protein } 136 \\
\text { Urate oxidase } \\
\text { Thymine-dna glycosylase } \\
\text { Hemoglobin } \alpha, \text { adult chain } 1 \\
\text { Phosphatidylserine-specific phospholipase a1 } \\
\text { Melanoma cell adhesion molecule } \\
\text { Ribosomal protein s } 9 \\
\text { Rho, gdp dissociation inhibitor (gdi) } \beta \\
\text { Ribosomal protein } 110 \mathrm{a} \\
\text { Phosphoglycerate kinase } 1 \\
\text { Syntaxin } 5 \text { a } \\
\text { G protein-coupled receptor, family c, group } 5, \text { member c } \\
\text { Syntaxin } 4 a \text { (placental) }\end{array}$ \\
\hline $\begin{array}{l}\text { Cell } \\
\text { proliferation }\end{array}$ & 1.58 & $\begin{array}{l}\text { Rn.22087 } \\
\text { Rn.9829 } \\
\text { Rn.9954 } \\
\text { Rn.2776 } \\
\text { Rn.59630 } \\
\text { Rn.106034 } \\
\text { Rn.55036 } \\
\text { Rn.98783 } \\
\text { Rn.1952 } \\
\text { Rn.17145 } \\
\text { Rn.4223 } \\
\text { Rn.84435 } \\
\text { Rn.71377 } \\
\text { Rn.11343 } \\
\text { Rn.13589 } \\
\text { Rn.2989 } \\
\text { Rn.37427 } \\
\text { Rn.98846 } \\
\text { Rn.55487 } \\
\text { Rn.41063 } \\
\text { Rn.11763 } \\
\text { Rn.61687 } \\
\text { Rn.47 } \\
\text { Rn.13322 }\end{array}$ & $\begin{array}{l}\text { Interferon induced transmembrane protein } 1 \\
\text { Advanced glycosylation end product-specific receptor } \\
\text { Transforming growth factor, } \beta \text { receptor ii } \\
\text { Beclin } 1 \text { (coiled-coil, myosin-like bcl2-interacting protein) } \\
\text { Similar to riken cdna b230339h12 } \\
\text { Ribosomal protein s27a } \\
\text { Ciliary neurotrophic factor receptor } \\
\text { Gm2 ganglioside activator protein } \\
\text { Surfactant associated protein b } \\
\text { Connective tissue growth factor } \\
\text { Dyskeratosis congenita } 1, \text { dyskerin } \\
\text { Glucose phosphate isomerase } \\
\text { Eukaryotic translation initiation factor } 4 \gamma, 3 \\
\text { Surfactant, pulmonary-associated protein a1 } \\
\text { Polymerase i and transcript release factor } \\
\text { Homeobox only domain } \\
\text { Transcription elongation factor b (siii), polypeptide } 3 \\
\text { Fibrinogen, } \alpha \text { polypeptide } \\
\text { Guanine nucleotide binding protein (g protein) } \\
\text { Sterol regulatory element binding factor } 2 \\
\text { Structural maintenance of chromosomes } 1 \text { like } 1 \text { (S. cerevisiae) } \\
\text { Phosphatidic acid phosphatase } 2 \mathrm{a} \\
\text { Hypoxanthine guanine phosphoribosyl transferase } \\
\text { Brf2, subunit of rna polymerase iii transcription initiation factor, brf1-like }\end{array}$ \\
\hline
\end{tabular}


Table IV. Continued.

\begin{tabular}{|c|c|c|c|}
\hline Classification & $\begin{array}{l}\text { Enrichment } \\
\text { score }\end{array}$ & UniGene & Annotation \\
\hline & & $\begin{array}{l}\text { Rn.12550 } \\
\text { Rn. } 94935 \\
\text { Rn. } 2759 \\
\text { Rn. } 92643 \\
\text { Rn.101762 } \\
\text { Rn.98685 } \\
\text { Rn.107334 } \\
\text { Rn. } 3036 \\
\text { Rn.32080 } \\
\text { Rn.15842 } \\
\text { Rn. } 9406 \\
\text { Rn. } 33218 \\
\text { Rn. } 36610\end{array}$ & $\begin{array}{l}\text { Nuclear factor of } \kappa \text { light chain gene enhancer in b-cells inhibitor, } \alpha \\
\text { Ribosomal protein s3a } \\
\text { C-src tyrosine kinase } \\
\text { KH-type splicing regulatory protein } \\
\text { Perp, tp } 53 \text { apoptosis effector } \\
\text { Thymine-dna glycosylase } \\
\text { Hemoglobin } \alpha \text {, adult chain } 1 \\
\text { Guanine nucleotide binding protein, } \alpha \text { inhibiting } 2 \\
\text { Allograft inflammatory factor } 1 \\
\text { Rho, gdp dissociation inhibitor (gdi) } \beta \\
\text { Necdin-like } 2 \\
\text { Syntaxin } 4 \mathrm{a} \text { (placental) } \\
\text { Tumor protein, translationally-controlled } 1\end{array}$ \\
\hline $\begin{array}{l}\text { Cellular lipid } \\
\text { metabolic } \\
\text { process }\end{array}$ & 1.34 & $\begin{array}{l}\text { Rn.3285 } \\
\text { Rn.10696 } \\
\text { Rn.1952 } \\
\text { Rn.3510 } \\
\text { Rn.41063 } \\
\text { Rn.61687 } \\
\text { Rn.5106 } \\
\text { Rn.80835 } \\
\text { Rn.19267 } \\
\text { Rn. } 98783\end{array}$ & $\begin{array}{l}\text { Diazepam binding inhibitor } \\
\text { Phosphatidylserine-specific phospholipase a1 } \\
\text { Surfactant associated protein b } \\
\text { Similar to bb128963 protein } \\
\text { Sterol regulatory element binding factor } 2 \\
\text { Phosphatidic acid phosphatase } 2 \text { a } \\
\text { 3-Hydroxy-3-methylglutaryl-coenzyme a synthase } 1 \\
\text { Dodecenoyl-coenzyme a } \delta \text { isomerase } \\
\text { Peroxisomal trans-2-enoyl-CoA reductase } \\
\text { Gm2 ganglioside activator protein }\end{array}$ \\
\hline $\begin{array}{l}\text { Defense } \\
\text { response }\end{array}$ & 1.3 & $\begin{array}{l}\text { Rn. } 9829 \\
\text { Rn.22087 } \\
\text { Rn. } 9954 \\
\text { Rn.32080 } \\
\text { Rn.2589 } \\
\text { Rn.2283 } \\
\text { Rn. } 98667 \\
\text { Rn.2776 } \\
\text { Rn.12550 } \\
\text { Rn.2267 }\end{array}$ & $\begin{array}{l}\text { Advanced glycosylation end product-specific receptor } \\
\text { Interferon induced transmembrane protein } 1 \\
\text { Transforming growth factor, } \beta \text { receptor ii } \\
\text { Allograft inflammatory factor } 1 \\
\text { Cysteine dioxygenase } 1 \text {, cytosolic } \\
\text { Lysozyme } \\
\text { Heat shock } 90 \text { kda protein } 1, \beta \\
\text { Beclin } 1 \text { (coiled-coil, myosin-like bcl2-interacting protein) } \\
\text { Nuclear factor of } \kappa \text { light chain gene enhancer in b-cells inhibitor, } \alpha \\
\text { Defensin } \beta 3\end{array}$ \\
\hline Transport & 1.11 & $\begin{array}{l}\text { Rn. } 9829 \\
\text { Rn. } 9954 \\
\text { Rn. } 54541 \\
\text { Rn. } 29258 \\
\\
\text { Rn. } 25717 \\
\text { Rn. } 98783 \\
\text { Rn. } 17145 \\
\text { Rn. } 3793 \\
\text { Rn. } 8509 \\
\text { Rn.1838 } \\
\text { Rn. } 82672 \\
\text { Rn.11343 } \\
\text { Rn.108012 } \\
\text { Rn. } 3264 \\
\text { Rn.12550 } \\
\text { Rn. } 92643 \\
\text { Rn.3285 }\end{array}$ & $\begin{array}{l}\text { Advanced glycosylation end product-specific receptor } \\
\text { Transforming growth factor, } \beta \text { receptor ii } \\
\text { Sodium channel, voltage-gated, type } 6, \alpha \text { polypeptide } \\
\text { Similar to atp synthase, h+ transporting, mitochondrial f0 complex, } \\
\text { subunit c (subunit 9), isoform } 2 \\
\text { Butyrophilin-like } 2 \text { (mhc class ii associated) } \\
\text { Gm2 ganglioside activator protein } \\
\text { Connective tissue growth factor } \\
\text { Similar to tensin } \\
\text { Transmembrane trafficking protein } 21 \\
\text { Chloride intracellular channel } 5 \\
\text { Vesicle-associated membrane protein } 8 \\
\text { Surfactant, pulmonary-associated protein a1 } \\
\text { Lysosomal-associated protein transmembrane } 4 a \\
\text { Signal sequence receptor, } \gamma \\
\text { Nuclear factor of } \kappa \text { light chain gene enhancer in b-cells inhibitor, } \alpha \\
\text { KH-type splicing regulatory protein } \\
\text { Diazepam binding inhibitor }\end{array}$ \\
\hline
\end{tabular}


Table IV. Continued.

\begin{tabular}{lll}
\hline Classification & $\begin{array}{c}\text { Enrichment } \\
\text { score }\end{array}$ & UniGene \\
\hline & $\mathrm{Rn} .3036$ & Annotation \\
& $\mathrm{Rn} .32080$ & Allograft inflammatory factor 1 \\
& $\mathrm{Rn} .107334$ & Hemoglobin $\alpha$, adult chain 1 \\
& $\mathrm{Rn} .25771$ & Heterogeneous nuclear ribonucleoprotein a1 \\
& $\mathrm{Rn} .15842$ & Rho, gdp dissociation inhibitor (gdi) $\beta$ \\
& $\mathrm{Rn} .5782$ & Syntaxin 5a \\
& $\mathrm{Rn} .33218$ & Syntaxin 4a (placental) \\
& $\mathrm{Rn} .36610$ & Tumor protein, translationally-controlled 1 \\
\hline
\end{tabular}

Table V. Gene lists of categories by the Gene Ontology (GO) Tree Machine.

\begin{tabular}{|c|c|c|c|}
\hline $\begin{array}{l}\text { Enriched GO } \\
\text { categories }\end{array}$ & $\begin{array}{l}\text { Gene } \\
\text { nos. }\end{array}$ & UniGene & Annotation \\
\hline Biosynthesis & 16 & $\begin{array}{l}\text { Rn.92643 } \\
\text { Rn.47 } \\
\text { Rn.3285 } \\
\text { Rn.2722 } \\
\text { Rn.40171 } \\
\text { Rn.5106 } \\
\text { Rn.71377 } \\
\text { Rn.6606 } \\
\text { Rn.103276 } \\
\text { Rn.3910 } \\
\text { Rn.61687 } \\
\text { Rn.108039 } \\
\text { Rn.8400 } \\
\text { Rn.2589 } \\
\text { Rn.109735 } \\
\text { Rn.106034 }\end{array}$ & $\begin{array}{l}\text { KH-type splicing regulatory protein } \\
\text { Hypoxanthine guanine phosphoribosyl transferase } \\
\text { Diazepam binding inhibitor } \\
\text { Ribosomal protein } \mathrm{L} 27 \mathrm{a} \\
\text { Ribosomal protein } \mathrm{S} 4, \mathrm{X} \text {-linked } \\
\text { 3-Hydroxy-3-methylglutaryl-Coenzyme A synthase } 1 \\
\text { Eukaryotic translation initiation factor } 4 \gamma, 3 \\
\text { Tissue specific transplantation antigen P35B } \\
\text { Eukaryotic translation initiation factor } 4, \gamma 2 \\
\text { Eukaryotic translation elongation factor } 1 \beta 2 \\
\text { Phosphatidic acid phosphatase } 2 \mathrm{a} \\
\text { Ribosomal protein L14 } \\
\text { Ribosomal protein } \mathrm{S} 12 \\
\text { Cysteine dioxygenase } 1, \text { cytosolic } \\
\text { Ribosomal protein } \mathrm{S} 9 \\
\text { Ribosomal protein } \mathrm{S} 27 \mathrm{a}\end{array}$ \\
\hline $\begin{array}{l}\text { Cellular } \\
\text { biosynthesis }\end{array}$ & 14 & $\begin{array}{l}\text { Rn.92643 } \\
\text { Rn.47 } \\
\text { Rn.2722 } \\
\text { Rn.40171 } \\
\text { Rn.71377 } \\
\text { Rn.6606 } \\
\text { Rn.103276 } \\
\text { Rn.3910 } \\
\text { Rn.61687 } \\
\text { Rn.108039 } \\
\text { Rn.8400 } \\
\text { Rn.2589 } \\
\text { Rn.109735 } \\
\text { Rn.106034 }\end{array}$ & $\begin{array}{l}\text { KH-type splicing regulatory protein } \\
\text { Hypoxanthine guanine phosphoribosyl transferase } \\
\text { Ribosomal protein } \mathrm{L} 27 \mathrm{a} \\
\text { Ribosomal protein } \mathrm{S} 4, \mathrm{X} \text {-linked } \\
\text { Eukaryotic translation initiation factor } 4 \text { gamma, } 3 \\
\text { Tissue specific transplantation antigen P35B } \\
\text { Eukaryotic translation initiation factor } 4, \gamma 2 \\
\text { Eukaryotic translation elongation factor } 1 \beta 2 \\
\text { Phosphatidic acid phosphatase } 2 \mathrm{a} \\
\text { Ribosomal protein } \mathrm{L} 14 \\
\text { Ribosomal protein } \mathrm{S} 12 \\
\text { Cysteine dioxygenase } 1 \text {, cytosolic } \\
\text { Ribosomal protein } \mathrm{S} 9 \\
\text { Ribosomal protein } \mathrm{S} 27 \mathrm{a}\end{array}$ \\
\hline $\begin{array}{l}\text { Macromolecule } \\
\text { biosynthesis }\end{array}$ & 11 & $\begin{array}{l}\text { Rn.106034 } \\
\text { Rn. } 2722 \\
\text { Rn.40171 } \\
\text { Rn.71377 } \\
\text { Rn.6606 } \\
\text { Rn.103276 }\end{array}$ & $\begin{array}{l}\text { KH-type splicing regulatory protein } \\
\text { Ribosomal protein L } 27 \text { a } \\
\text { Ribosomal protein } \mathrm{S} 4, \mathrm{X} \text {-linked } \\
\text { Eukaryotic translation initiation factor } 4 \gamma, 3 \\
\text { Tissue specific transplantation antigen } \mathrm{P} 35 \mathrm{~B} \\
\text { Eukaryotic translation initiation factor } 4, \gamma 2\end{array}$ \\
\hline
\end{tabular}


Table V. Continued.

\begin{tabular}{|c|c|c|c|}
\hline $\begin{array}{l}\text { Enriched GO } \\
\text { categories }\end{array}$ & $\begin{array}{l}\text { Gene } \\
\text { nos. }\end{array}$ & UniGene & Annotation \\
\hline & & $\begin{array}{l}\text { Rn.3910 } \\
\text { Rn.108039 } \\
\text { Rn.8400 } \\
\text { Rn.109735 } \\
\text { Rn.106034 }\end{array}$ & $\begin{array}{l}\text { Eukaryotic translation elongation factor } 1 \beta 2 \\
\text { Ribosomal protein L14 } \\
\text { Ribosomal protein S12 } \\
\text { Ribosomal protein S9 } \\
\text { Ribosomal protein } \mathrm{S} 27 \mathrm{a}\end{array}$ \\
\hline $\begin{array}{l}\text { Protein } \\
\text { biosynthesis }\end{array}$ & 11 & $\begin{array}{l}\text { Rn. } 92643 \\
\text { Rn.2722 } \\
\text { Rn. } 40171 \\
\text { Rn. } 71377 \\
\text { Rn.6606 } \\
\text { Rn.103276 } \\
\text { Rn.3910 } \\
\text { Rn.108039 } \\
\text { Rn. } 8400 \\
\text { Rn.109735 } \\
\text { Rn.106034 }\end{array}$ & $\begin{array}{l}\text { KH-type splicing regulatory protein } \\
\text { Ribosomal protein L27a } \\
\text { Ribosomal protein S4, X-linked } \\
\text { Eukaryotic translation initiation factor } 4 \gamma, 3 \\
\text { Tissue specific transplantation antigen P35B } \\
\text { Eukaryotic translation initiation factor } 4, \gamma 2 \\
\text { Eukaryotic translation elongation factor } 1 \beta 2 \\
\text { Ribosomal protein L14 } \\
\text { Ribosomal protein S12 } \\
\text { Ribosomal protein S9 } \\
\text { Ribosomal protein S27a }\end{array}$ \\
\hline $\begin{array}{l}\text { Protein kinase } \mathrm{C} \\
\text { activation }\end{array}$ & 2 & $\begin{array}{l}\text { Rn.61687 } \\
\text { Rn.55487 }\end{array}$ & $\begin{array}{l}\text { Phosphatidic acid phosphatase } 2 \mathrm{a} \\
\text { Guanine nucleotide binding protein ( } \mathrm{G} \text { protein, } \beta \text { polypeptide } 2 \text { like } 1 \text { ) }\end{array}$ \\
\hline Cytolysis & 2 & $\begin{array}{l}\mathrm{Rn} .47 \\
\mathrm{Rn} .2283\end{array}$ & $\begin{array}{l}\text { Hypoxanthine guanine phosphoribosyl transferase } \\
\text { Lysozyme }\end{array}$ \\
\hline $\begin{array}{l}\text { Vesicle } \\
\text { targeting }\end{array}$ & 2 & $\begin{array}{l}\mathrm{Rn} .5782 \\
\mathrm{Rn} .8509\end{array}$ & $\begin{array}{l}\text { Syntaxin 5a } \\
\text { Transmembrane emp24-like trafficking protein } 10 \text { (yeast) }\end{array}$ \\
\hline $\begin{array}{l}\text { Regulation of liquid } \\
\text { surface tension }\end{array}$ & 2 & $\begin{array}{l}\text { Rn.1952 } \\
\text { Rn.11343 }\end{array}$ & $\begin{array}{l}\text { Surfactant associated protein B } \\
\text { Surfactant, pulmonary-associated protein A1 }\end{array}$ \\
\hline mRNA transport & 2 & $\begin{array}{l}\text { Rn. } 92643 \\
\text { Rn. } 25771\end{array}$ & $\begin{array}{l}\text { KH-type splicing regulatory protein } \\
\text { Heterogeneous nuclear ribonucleoprotein A1 }\end{array}$ \\
\hline $\begin{array}{l}\text { mRNA export } \\
\text { from nucleus }\end{array}$ & 2 & $\begin{array}{l}\text { Rn.92643 } \\
\text { Rn.25771 }\end{array}$ & $\begin{array}{l}\text { KH-type splicing regulatory protein } \\
\text { Heterogeneous nuclear ribonucleoprotein A1 }\end{array}$ \\
\hline
\end{tabular}

pathways was 'SNARE interactions in vesicular transport'. SNARE proteins are a large superfamily of proteins that consists of more than 60 members in yeast and mammalian cells, and play an integral part in membrane fusion events in the secretory and endocytic pathways (27). Syntaxin 5a was found in our analysis to be regulated in response to acupuncture. This protein is a member of the integrated SNARE proteins that participate in exocytosis, which mediates endoplasmic reticulum to Golgi transport. These results suggest that acupuncture may activate the processes of membrane fusion and intercellular signal transduction, which regulate the transport of substances into or out of cells.

KEGG pathway selection provides a platform for integrating and elucidating useful data. The matching of pathways, such as 'tight junction', 'adherens junction', 'focal adhesion', 'cell communication', 'cytokine-cytokine receptor interaction' and 'regulation of actin cytoskeleton', in our research suggests that the process of acupuncture activates intercellular signal transduction. Tight and adherens junctions are 2 types of intercellular junctions in vertebrates (28). The local electrical activity of the cell membrane, interactions with the cytoskeleton or the activation of certain receptors may play a part in activating these signaling pathways. Based on our data, we suggest that interactions between cells and re-arrangement of the cytoskeleton occur after acupuncture, and signals are transferred from one cell to another. The process of cell communication may last for a certain time, and then cells relay the message and certain processes commence, such as new mRNA transcription, synthesizing macromolecular proteins and enzymes, and conducting purine metabolism. $\beta$-actin and the $\mathrm{c}$-src tyrosine kinase were 2 genes that were regulated by acupuncture. $\beta$-actin is an important component of the cytoskeleton, and it participates in the local signal exchange between cells, their surroundings or with other cells. c-src tyrosine kinase plays a role in phosphorylation and acidification in cell-cell interactions (29), which also controls the dynamic actin cytoskeleton (30). The results from our study suggest that acupuncture may regulate intercellular signal transduction in normal rat lung 
Table VI. Kyoto Encyclopedia of Genes and Genomes (KEGG) pathways of differentially expressed tags.

\begin{tabular}{|c|c|c|c|}
\hline Pathway name & Gene nos. & UniGene & Annotation \\
\hline $\begin{array}{l}\text { SNARE interactions in } \\
\text { vesicular transport }\end{array}$ & 3 & $\begin{array}{l}\text { Rn.82672 } \\
\text { Rn.5782 } \\
\text { Rn.33218 }\end{array}$ & $\begin{array}{l}\text { Vesicle-associated membrane protein } 8 \\
\text { Syntaxin } 5 \mathrm{a} \\
\text { Syntaxin } 4 \mathrm{a}\end{array}$ \\
\hline Tight junction & 3 & $\begin{array}{l}\text { Rn.3036 } \\
\text { Rn.94978 } \\
\text { Rn.4108 }\end{array}$ & $\begin{array}{l}\text { Guanine nucleotide binding protein, } \alpha \text { inhibiting } 2 \\
\text { Actin, } \beta \\
\text { Protein phosphatase } 2 \text { (formerly } 2 \mathrm{a} \text { ), } \\
\text { regulatory subunit a (pr } 65 \text { ), } \alpha \text { isoform }\end{array}$ \\
\hline ECM-receptor interaction & 2 & $\begin{array}{l}\text { Rn.53801 } \\
\text { Rn.100627 }\end{array}$ & $\begin{array}{l}\text { Procollagen, type iv, } \alpha 1 \\
\text { Fibronectin type iii domain containing } 3\end{array}$ \\
\hline Adherens junction & 2 & $\begin{array}{l}\text { Rn.9954 } \\
\text { Rn.94978 }\end{array}$ & $\begin{array}{l}\text { Transforming growth factor, } \beta \text { receptor ii } \\
\text { Actin, } \beta\end{array}$ \\
\hline Long-term depression & 2 & $\begin{array}{l}\text { Rn.3036 } \\
\text { Rn.4108 }\end{array}$ & $\begin{array}{l}\text { Guanine nucleotide binding protein, } \alpha \text { inhibiting } 2 \\
\text { Protein phosphatase } 2 \text { (formerly } 2 \text { a), } \\
\text { regulatory subunit a ( } \operatorname{pr} 65), \alpha \text { isoform }\end{array}$ \\
\hline Small cell lung cancer & 2 & $\begin{array}{l}\text { Rn.53801 } \\
\text { Rn.12550 }\end{array}$ & $\begin{array}{l}\text { Procollagen, type iv, } \alpha 1 \\
\text { Nuclear factor of } \kappa \text { light chain gene enhancer in b-cells inhibitor, } \alpha\end{array}$ \\
\hline TGF- $\beta$ signaling pathway & 2 & $\begin{array}{l}\text { Rn.9954 } \\
\text { Rn.4108 }\end{array}$ & $\begin{array}{l}\text { Transforming growth factor, } \beta \text { receptor ii } \\
\text { Protein phosphatase } 2 \text { (formerly } 2 \mathrm{a}) \\
\text { regulatory subunit a ( } \mathrm{pr} 65), \alpha \text { isoform }\end{array}$ \\
\hline $\begin{array}{l}\text { Chronic myeloid } \\
\text { leukemia }\end{array}$ & 2 & $\begin{array}{l}\text { Rn.9954 } \\
\text { Rn.12550 }\end{array}$ & $\begin{array}{l}\text { Transforming growth factor, } \beta \text { receptor ii } \\
\text { Nuclear factor of } \kappa \text { light chain gene enhancer in b-cells inhibitor, } \alpha\end{array}$ \\
\hline $\begin{array}{l}\text { Antigen processing } \\
\text { and presentation }\end{array}$ & 2 & $\begin{array}{l}\text { Rn.98667 } \\
\text { Rn.25717 }\end{array}$ & $\begin{array}{l}\text { Heat shock } 90 \text { kda protein } 1, \beta \\
\text { Butyrophilin-like } 2 \text { (mhc class ii associated) }\end{array}$ \\
\hline Purine metabolism & 2 & $\begin{array}{l}\text { Rn. } 11330 \\
\text { Rn. } 47\end{array}$ & $\begin{array}{l}\text { Urate oxidase } \\
\text { Hypoxanthine guanine phosphoribosyl transferase }\end{array}$ \\
\hline $\begin{array}{l}\text { Leukocyte transendothelial } \\
\text { migration }\end{array}$ & 2 & $\begin{array}{l}\text { Rn.3036 } \\
\text { Rn.94978 }\end{array}$ & $\begin{array}{l}\text { Guanine nucleotide binding protein, } \alpha \text { inhibiting } 2 \\
\text { Actin, } \beta\end{array}$ \\
\hline Cell communication & 2 & $\begin{array}{l}\text { Rn.94978 } \\
\text { Rn.53801 }\end{array}$ & $\begin{array}{l}\text { Actin, } \beta \\
\text { Procollagen, type iv, } \alpha 1\end{array}$ \\
\hline $\begin{array}{l}\text { Cytokine-cytokine } \\
\text { receptor interaction }\end{array}$ & 2 & $\begin{array}{l}\text { Rn.9954 } \\
\text { Rn.55036 }\end{array}$ & $\begin{array}{l}\text { Transforming growth factor, } \beta \text { receptor ii } \\
\text { Ciliary neurotrophic factor receptor }\end{array}$ \\
\hline Focal adhesion & 2 & $\begin{array}{l}\text { Rn.94978 } \\
\text { Rn.53801 }\end{array}$ & $\begin{array}{l}\text { Actin, } \beta \\
\text { Procollagen, type iv, } \alpha 1\end{array}$ \\
\hline $\begin{array}{l}\text { Regulation of actin } \\
\text { cytoskeleton }\end{array}$ & 2 & $\begin{array}{l}\text { Rn.94978 } \\
\text { Rn.2759 }\end{array}$ & $\begin{array}{l}\text { Actin, } \beta \\
\text { C-src tyrosine kinase }\end{array}$ \\
\hline
\end{tabular}

SNARE, soluble (N-ethylmaleimide-sensitive fusion) NSF attachment protein receptor; ECM, extracellular matrix; TGF, transforming growth factor.

tissue through specific genes, such as $\beta$-actin and c-src tyrosine kinase.

We found that the gene expression profile in response to acupuncture under normal conditions shares similar DAVID gene functional classifications and GO categories with the gene expression profiles of asthmatic rats in response to acupuncture (20). In the DAVID gene functional classifica- tions, the categories entitled 'cellular biosynthetic process', 'cellular lipid metabolic process' and 'cellular process' were found to change in response to acupuncture in normal and asthmatic rats. Furthermore, in the GO Tree Machine analysis, the gene categories entitled 'regulation of liquid surface tension' and 'biosynthesis' were found to be regulated by acupuncture in both types of rats. However, the genes were 
different under the same functional classification and enriched GO category of biological process. Therefore, this suggests that acupuncture initiates different branches of the same biological processes under normal and morbid conditions. This comparison demonstrates that the cellular biosynthesis and cellular lipid metabolism are the common regulations of biological processes in response to acupuncture in normal and asthmatic rats.

In this study, we present the gene expression profiles of lung tissues derived from normal and acupuncture-treated, normal rats by SAGE analysis. A series of physiological alterations occurs after acupuncture treatment, and the essential effects of acupuncture include the regulation of biosynthesis, transportation and metabolism. Acupuncture orchestrates the activity of an organism by regulating the expression of specific genes. Cellular biosynthesis and cellular lipid metabolism are the common regulations of biological processes in response to acupuncture under normal and morbid conditions, which may be the general physiological effects of acupuncture.

\section{Acknowledgements}

This study was supported by the National Natural Science Foundation of China (no. 30873299, 90409014, 81001548, 81173341, 81173332), the 'Chen Guang' Project supported by the Shanghai Municipal Education Commission and Shanghai Education Development Foundation (10CG45), the Shanghai Leading Academic Discipline Project (S30304), and the Key Program of the State Administration of Traditional Chinese Medicine of China.

\section{References}

1. Use of acupuncture in modern health care. WHO Chron 34: 294-301, 1980

2. World Health Organization: Acupuncture: Review and Analysis of Reports on Controlled Clinical Trials, 2002.

3. Acupuncture. NIH Consens Statement 15: 1-34, 1997.

4. NIH Consensus Development Panel on Acupuncture: Acupuncture. JAMA 280: 1518-1524, 1998.

5. Dean-Clower E, Doherty-Gilman AM, Keshaviah A, et al: Acupuncture as palliative therapy for physical symptoms and quality of life for advanced cancer patients. Integr Cancer Ther 9: $158-167,2010$.

6. Ouyang $\mathrm{H}$ and Chen JD: Review article: therapeutic roles of acupuncture in functional gastrointestinal disorders. Aliment Pharmacol Ther 20: 831-841, 2004.

7. Ernst E and Lee MS: Acupuncture for rheumatic conditions: an overview of systematic reviews. Rheumatology (Oxford) 49 1957-1961, 2010.

8. Han JS: Acupuncture analgesia: areas of consensus and controversy. Pain 152: S41-S48, 2011

9. Irnich D, Salih N, Offenbacher M and Fleckenstein J: Is sham laser a valid control for acupuncture trials. Evid Based Complement Alternat Med 2011: 485945, 2011.

10. Hammerschlag R: The physiology of acupuncture. In: Contemporary Chinese Medicine and Acupuncture. Cassidy CM (ed). Churchill Livingstone, 2001.
11. Hammerschlag R, Langevin HM, Lao L and Lewith G: Physiological dynamics of acupuncture: correlations and mechanisms. In: Acupuncture Research: Strategies for Establishing an Evidence Base. MacPherson H (ed). Elsevier, Philadelphia, PA, 2007.

12. Huang Y, Li TL, Lai XS, et al: Functional brain magnetic resonance imaging in healthy people receiving acupuncture at Waiguan versus Waiguan plus Yanglingquan points: a randomized controlled trial. Zhong Xi Yi Jie He Xue Bao 7: 527-531, 2009.

13. Yamaguchi N, Takahashi T, Sakuma M, et al: Acupuncture regulates leukocyte subpopulations in human peripheral blood. Evid Based Complement Alternat Med 4: 447-453, 2007.

14. Lin ZP, Lan LW, He TY, et al: Effects of acupuncture stimulation on recovery ability of male elite basketball athletes. Am J Chin Med 37: 471-481, 2009.

15. Pariente J, White P, Frackowiak RS and Lewith G: Expectancy and belief modulate the neuronal substrates of pain treated by acupuncture. Neuroimage 25: 1161-1167, 2005.

16. Vickland V, Rogers C, Craig A and Tran Y: Anxiety as a factor influencing physiological effects of acupuncture. Complement Ther Clin Pract 15: 124-128, 2009.

17. Kim SK and Bae H: Acupuncture and immune modulation. Auton Neurosci 157: 38-41, 2010.

18. Vickland V, Rogers C, Craig A and Tran Y: Electrodermal activity as a possible physiological marker for acupuncture. Complement Ther Clin Pract 14: 83-89, 2008.

19. Velculescu VE, Zhang L, Zhou W, et al: Characterization of the yeast transcriptome. Cell 88: 243-251, 1997.

20. Yin LM, Jiang GH, Wang Y, et al: Use of serial analysis of gene expression to reveal the specific regulation of gene expression profile in asthmatic rats treated by acupuncture. J Biomed Sci 16: 46, 2009.

21. Yin LM, Jiang GH, Wang Y, et al: Serial analysis of gene expression in a rat lung model of asthma. Respirology 13: 972-982, 2008.

22. Livak KJ and Schmittgen TD: Analysis of relative gene expression data using real-time quantitative PCR and the 2(-Delta Delta C(T)) Method. Methods 25: 402-408, 2001.

23. Dennis G Jr, Sherman BT, Hosack DA, et al: DAVID: Database for annotation, visualization, and integrated discovery. Genome Biol 4: P3, 2003.

24. Zhang B, Schmoyer D, Kirov S and Snoddy J: GO Tree Machine (GOTM): a web-based platform for interpreting sets of interesting genes using Gene Ontology hierarchies. BMC Bioinformatics 5: 16-23, 2004.

25. Yang ES, Li PW, Nilius B and Li G: Ancient Chinese medicine and mechanistic evidence of acupuncture physiology. Pflugers Arch 462: 645-653, 2011.

26. Strange K: From genes to integrative physiology: ion channel and transporter biology in Caenorhabditis elegans. Physiol Rev 83: $377-415,2003$.

27. Lundeberg $\mathrm{T}$ and Stener-Victorin E: Is there a physiological basis for the use of acupuncture in pain? International Congress Series 1238: 3-10, 2002.

28. Bazzoni G and Dejana E: Endothelial cell-to-cell junctions: molecular organization and role in vascular homeostasis. Physiol Rev 84: 869-901, 2004.

29. Lau AF: c-Src: bridging the gap between phosphorylation- and acidification-induced gap junction channel closure. Sci STKE 2005: pe33, 2005.

30. Avizienyte E, Keppler M, Sandilands E, et al: An active Src kinase-beta-actin association is linked to actin dynamics at the periphery of colon cancer cells. Exp Cell Res 313: 3175-3188, 2007. 